\title{
75 let kardiologie na Královských Vinohradech
}

\author{
Jana Málková', Zbyněk Straka², Pavel Gregor', Martin Herold'1, Martin Bernat , Miroslav Bulvas', Petr Widimský1 \\ ' III. interní-kardiologická klinika, Kardiocentrum, Fakultní nemocnice Královské Vinohrady a 3. lékařská fakulta Univerzity Karlovy, \\ 2 Kardiochirurgická klinika, Kardiocentrum, Fakultní nemocnice Královské Vinohrady a 3. lékařská fakulta Univerzity Karlovy, \\ ${ }^{3}$ Chirurgická klinika, Fakultní nemocnice Královské Vinohrady a 3. lékařská fakulta Univerzity Karlovy, Praha, Česká republika
}

Adresa: prof. MUDr. Petr Widimský, DrSc., FESC, Kardiocentrum, FNKV a 3. LF UK, Ruská 87, 10000 Praha 10, Česká republika, e-mail: widim@fnkv.cz

Kardiologické oddělení (pod názvem srdeční oddělení) bylo v nemocnici na Královských Vinohradech založeno v roce 1935. Letos si tedy připomínáme 75 let od tohoto data. Dovolujeme si proto ohlédnout se za minulostí kardiologie (ale i kardiochirurgie, angiologie a cévní chirurgie) v této nemocnici. Závěrem prezentujeme její přítomnost.

Král Karel IV. založil zvláštním privilegiem $\mathrm{v}$ roce 1358 Hory Viničné, v pozdější terminologii Vinohrady. $\mathrm{V}$ roce 1843 bylo na Viničných Horách pouze 68 samot se 169 obyvateli, roku 1849 byly tyto usedlosti sloučeny v samostatnou katastrální obec, od roku 1867 nazývanou Královské Vinohrady. Začalo se tam rychle stavět. V roce 1877 dostala severní část název Žižkov. V roce 1879 byly Královské Vinohrady povýšeny na město. V roce 1900 již měly 50000 obyvatel. Proto se radní rozhodli vybudovat nemocnici. Nemocnice Královské Vinohrady byla otevřena roku 1902, tou dobou ještě Královské Vinohrady byly samostatným městem (dokonce třetím největším - po Praze a Brně - v nově vzniklém Československu!). S Prahou byly Královské Vinohrady sloučeny až roku 1922.

\section{5-1978: počátky kardiologie ve FNKV}

Již v roce 1935 vzniklo ve vinohradské nemocnici lůžkové srdeční oddělení (v pavilonu D), vedené Stanislavem Mentlem (jeden ze zakládajících členů Československé kardiologické společnosti - založena 13. prosince 1929). Profesor Mentl a jeho asistent Všetička byli pověstní svým laskavým chováním $\mathrm{k}$ pacientům. $\mathrm{V}$ té době bylo základem fyzikální vyšetření, RTG hrudníku a primitivní EKG. Používalo se pouze asi deset léků a jejich kombinace. Mentl pacientům dával magistraliter prripravené prášky složené z malé dávky luminalu (barbiturát) a výtažku rulíku (belladony). Mentlovy rozepsané prášky (působící na vegetativní systém) se $\mathrm{v}$ nemocnici občas používaly ještě v sedmdesátých letech 20 . století, kdy byl celostátní nedostatek léků na anginu pectoris.
V padesátých letech 20. století byl přednostou I. interní kliniky Vratislav Jonáš, který napsal vynikající tř́́dílnou monografii Klinická kardiologie a vychoval řadu významných žáků. Z nich nejznámějšími byli Pavel Kozák a Vlastimil Višek. Víšek byl v letech 1970-1990 přednostou II. interní kliniky, umístěné v nově vybudovaném pavilonu S. Do této kliniky bylo včleněno existující srdeční oddělení (primár Bedřich Sobotka).

Josef Flek koncem šedesátých let 20. století v pavilonu E vytvořil monitorovaná lůžka - zárodek pozdější moderní koronární jednotky v pavilonu S - a v roce 1974 založil pojízdnou koronární jednotku - pionýrskou předzvěst dnešních plně vybavených vozů záchranné služby. Tehdejší ředitel nemocnice Václav Zeman tuto myšlenku podpořil. Pojízdná koronární jednotka svážela do pavilonu S nemocné s akutním infarktem myokardu z Prahy 3 a Prahy 10. Na každý výjezd jel lékař, řidič a medik-sanitár. V této funkci mediků-sanitářů pracovali např. Luděk Bajgar, Jan Calta, Vladimír Dobiáš, Jan Holeček, Bohumil Seifert, Rudolf Špaček, Jan Tošovský, Jiří Widimský, Petr Widimský a další.

Do šedesátých let 20. století se datují i počátky cévní chirurgie na Chirurgické klinice FNKV (vedené prof. Polákem), spojené s osobou Vladimíra Nahodila. Nahodil na počátku 70. let publikoval dvě monografie o cévní chirurgii - první svého druhu v Československu. Jeho pokračovateli byli Josef Kalný a později Martin Bernat.

\section{9-1990: vznik a rozvoj invazivní kardiologie a echokardiografie}

V roce 1978 nahradil předčasně zesnulého J. Fleka ve funkci vedoucího kardiologie na II. interní klinice Václav Červen$\boldsymbol{k} \boldsymbol{a}$, který přišel z Ústřední vojenské nemocnice. Pod jeho vedením a za velké podpory přednosty kliniky V. Víska se kardiologie začala dynamicky rozvíjet. V roce 1979 II. interní klinika získala jako první v Československu dvojrozměrný 
Významná data v historii kardiologie na Královských Vinohradech

\begin{tabular}{|c|c|}
\hline 11. 5. 1902 & Otevření nové nemocnice na Královských Vinohradech \\
\hline 13. 12.1929 & Založení Československé kardiologické společnosti (mezi zakladateli též Stanislav Mentl z vinohradské nemocnice) \\
\hline 1935 & Vznik srdečního oddělení nemocnice Královské Vinohrady (S. Mentl) \\
\hline 1938 & Stanislav Mentl ministrem veřejného zdraví a tělesné výchovy ve vládě ČSR \\
\hline 1942-1946 & Stanislav Mentl prezidentem ČKS \\
\hline 1953 & $\begin{array}{l}\text { Rozdělení LF UK na tři fakulty - vznik Lékařské fakulty hygienické Univerzity Karlovy (v roce } 1990 \text { přejmenována na 3. lékařskou } \\
\text { fakultu UK) }\end{array}$ \\
\hline 1950-1962 & Vydání rozsáhlé třídílné učebnice kardiologie V. Jonášem \\
\hline 1970 & $\begin{array}{l}\text { Splynutí srdečního oddělení FNKV se II. interní klinikou FNKV a LFH UK (přednosta kliniky: Vlastimil Víšek, vedoucí kardiologického } \\
\text { oddělení: Josef Flek) }\end{array}$ \\
\hline 1974-1985 & Pojízdná koronární jednotka (V. Víšek, J. Flek, S. Hrdlička) \\
\hline 1979 & $\begin{array}{l}\text { První dvojrozměrná echokardiografie v Československu (P. Gregor, P. Widimský), vyšetřování nemocných se vzácnými vadami z celé } \\
\text { republiky }\end{array}$ \\
\hline 1981 & Nová katetrizační laboratoř na II. interní klinice - založení invazivní kardiologie (V. Červenka) \\
\hline 1982 & $\begin{array}{l}\text { První intervenční léčba akutního infarktu myokardu (intrakoronární trombolýzou, od r. } 1984 \text { též akutní PTCA, V. Červenka) } \\
\text { v Československu }\end{array}$ \\
\hline 1984 & První česky psaná učebnice echokardiografie (P. Gregor, P. Widimský) \\
\hline 1989 & První československý PTCA workshop (V. Červenka) \\
\hline 1991 & Zahájen program trvalé kardiostimulace (S. Hrdlička, M. Herold) \\
\hline 1. 10. 1995 & $\begin{array}{l}\text { Zavedení nonstop služeb pro primární PTCA jako jediné reperfuzní metody u infarktu myokardu (ukončeno používání trombolýzy } \\
\text { v této indikaci ve FNKV - první pracoviště v ČR, P. Widimský, J. Dvořák) }\end{array}$ \\
\hline 5. 10. 1995 & Vznik Kardiochirurgického oddělení (později kliniky) FNKV (Z. Straka) \\
\hline 1.7. 1996 & $\begin{array}{l}\text { Vznik Kardiocentra FNKV spojením kardiologických oddělení obou interních klinik + kardiochirurgického oddělení } \\
\text { (P. Widimský) }\end{array}$ \\
\hline 1997-1999 & Studie PRAGUE-1 \\
\hline 1997 & $\begin{array}{l}\text { Připojení kardiologického oddělení (P. Kohout, V. Bufka) bývalé nemocnice MV ČR ke Kardiocentru FNKV. Kardiocentrum má } \\
\text { od tohoto spojení celkem } 136 \text { lůžek, kardiologické části však ještě stále jsou součástí dvou interních klinik (M. Anděl, J. Horák). }\end{array}$ \\
\hline 1999 & První prezentace v prestižní sekci Hot Lines na kongresu ESC (studie PRAGUE-1) \\
\hline 1. 8. 2001 & $\begin{array}{l}\text { Vznik III. interní-kardiologické kliniky FNKV a 3. LF UK - spojení tří kardiologií ve FNKV v jednu (iniciátoři: P. Widimský, } \\
\text { P. Gregor, M. Herold, R. Špaček) }\end{array}$ \\
\hline 2001 & První implantace automatického defibrilátoru (ICD - D. Heřman, J. Kletenský) \\
\hline 2002 & Václav Klaus slavnostně otevřel na kardiologické klinice novou koronární jednotku - největší v ČR \\
\hline 2004-2008 & P. Widimský členem výboru a viceprezidentem Evropské kardiologické společnosti \\
\hline 1. 7. 2008 & Přičlenění oboru angiologie ke kardiologické klinice \\
\hline
\end{tabular}

echokardiografický př́stroj. Echokardiografii na klinice rozvinuli mladí (tehdy 25- až 27letí) lékaři Pavel Gregor a Petr Widimský. Stali se průkopníky této diagnostické metody i v rámci celého Československa a v roce 1984 vydali první česky psanou učebnici Echokardiografie, která byla oceněna jako nejlepší kniha vydavatelství Avicenum $\mathrm{v}$ tom roce. Kniha vyšla ve druhém rozšířeném vydání ještě $\mathrm{v}$ roce 1991. Preventivní kardiologií se v téže době zabývala Jana Málková.

V roce 1981 byl na II. interní klinice v pavilonu S v př́izemí otevřen nový moderní katetrizační sál. Václav Červenka (který měl zkušenosti s invazivní kardiologií ze svého předchozího působišstě) vytvořil tým katetrizujících lékařu (Jaroslav Dvořák, Tamara Sládková, Petr Widimský) a na klinice se začaly pravidelně provádět koronarografie a oboustranné srdeční katetrizace. Pacienti s nálezy vhodnými ke kardiochirurgické operaci byli v 80. letech posíláni do Ústřední vojenské nemocnice. Poté, co tamější kardiochirurgie zanikla, byli nemocní posíláni k srdečním operacím do Hradce Králové, později i do IKEM a do VFN.

Pavel Gregor a Petr Widimský se s velkým nadšením vrhli i do vědecké práce a brzy se svými výsledky začali prosazovat i v zahraničí. V roce 1982 tak P. Widimský prezentoval výsledky echokardiografického vyšetřování akutních infarktů myokardu na mezinárodním symposiu ve švýcarském Lausanne. Zde byly poprvé představeny americké práce o intrakoronární trombolytické léčbě akutního infarktu myokardu. Pro tuto myšlenku se okamžitě nadchl i V. Červenka a ještě téhož roku touto novou metodou ošetřil prvního nemocného $s$ předním transmurálním infarktem. Výsledek byl tak přesvědčivý, že tento pacient je dodnes naživu a má téměř normální funkci levé komory. Tak byla vlastně zahájena dlouhá tradice katetrizační léčby srdečních infarktů, kterou se vinohradská nemocnice 


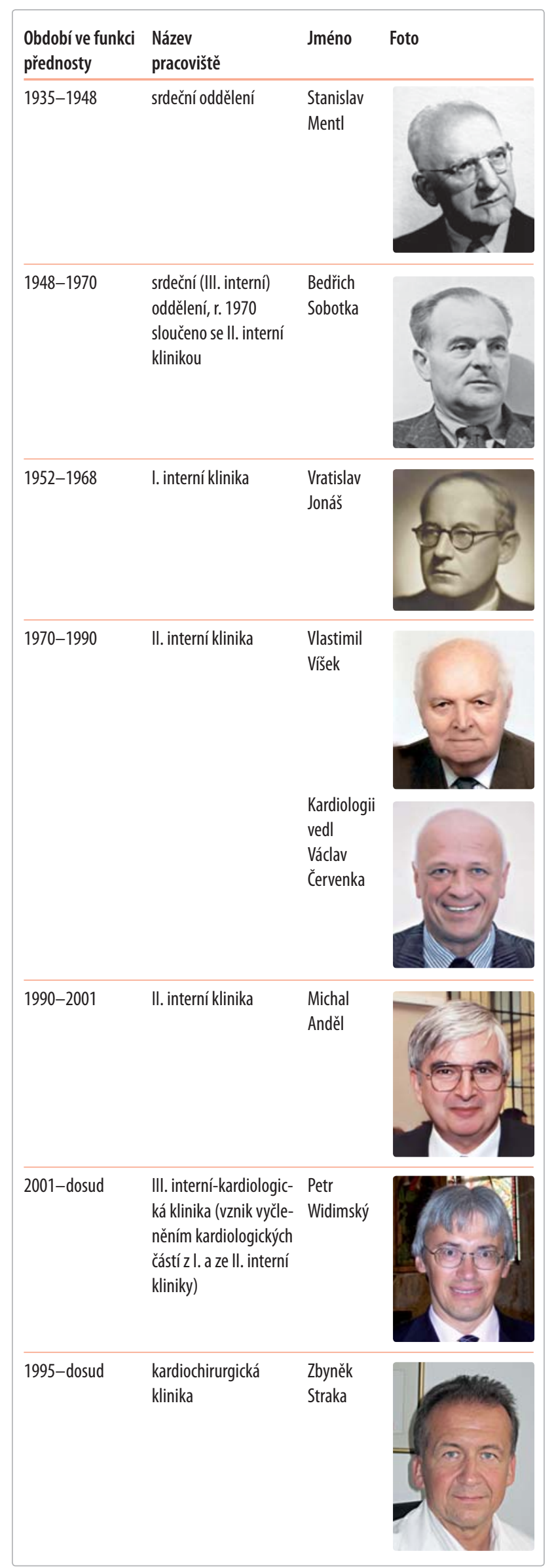

Přednostové kardiologicky zaměřených oddělení či klinik ve FNKV později proslavila i v zahraničí. O dva roky později (1984) pak provedl V. Červenka u nemocné s kontraindikací trombolýzy první primární perkutánní transluminální koronární angioplastiku (PTCA). V. Červenka uspořádal 7. 12. 1989 první PTCA workshop. Prezentováno bylo 221 PTCA provedených za šest let od roku 1983, z toho 42 u akutního infarktu myokardu.

Během roku 1990 V. Víška v čele II. interní kliniky vystř́ídal Michal Anděl. Na konci roku 1990 V. Červenka odešel z FNKV na místo přednosty Interního oddělení Ústřední vojenské nemocnice.

\section{1-1995: rozvoj primárních PTCA jako léčby infarktu myokardu}

Po odchodu V. Červenky nastala několikaměsíční doba nejistoty ohledně budoucnosti kardiologie ve FNKV. Koncem roku 1991 pověřil Michal Anděl vedením kardiologie na II. interní klinice P. Gregora (neinvazivní kardiologie, standardní lůžka) a P. Widimského (invazivní kardiologie, akutní lůžka). P. Widimský se $\mathrm{v}$ té době právě vrátil $\mathrm{z}$ ročního výzkumného pobytu $\mathrm{v}$ Nizozemsku a v letech 1992-1994 se tam opakovaně vracel s cílem naučit se dobře koronární angioplastiky včetně akutních PTCA při infarktu myokardu. Současně s otevřením nové kardiochirurgie (viz níže) zahájili kardiologové ve FNKV od října 1995 jako první v ČR program systematické léčby $v$ šech nemocných $s$ akutním infarktem myokardu primární PTCA. Nemocniční mortalita pacientů s transmurálním infarktem myokardu klesla prakticky ze dne na den z $11 \%$ na $4 \%$.

Tyto výsledky vedly k zamyšlení, jak poskytnout tuto šanci na záchranu života většímu počtu nemocných než jen těm z Prahy 3 a z Prahy 10 (v té době byli do FNKV přijímáni převážně jen nemocní $\mathrm{z}$ těchto dvou pražských obvodů). Vznikla myšlenka na studii PRAGUE, jejiž historie byla již popsána v č́sle 10 Cor et Vasa 2009.

V téže době také Stanislav Hrdlička zahájil program implantací kardiostimulátorů a elektrofyziologických vyšetření.

\section{5-2001: začátky kardiochirurgie, vznik kardiocentra a III. interní-kardiologické kliniky}

Fenomenální chirurg Emerich Polák (přednosta vinohradské chirurgie v letech 1935-1971) se mimo jiné věnoval hrudní chirurgii podle technických možností té doby. Operace mitrálních stenóz na zavřeném srdci (komisurolýzy) prováděl na Vinohradech krátce se svými žáky Vladimírem Vojtíškem a Antonínem Kosteleckým. Skutečný začátek kardiochirurgie ve FNKV je však spojen až s datem 5. řínna 1995, kdy byla na nově zřízeném kardiochirurgickém oddělení (později změněném na kliniku) provedena první operace srdce v mimotělním oběhu. Toto oddělení vybudoval mladý kardiochirurg z IKEM Zbyněk Straka za velké podpory tehdejši ř reditelky nemocnice Zuzany Roithové. Strakovým zástupcem a vedoucím kardioanestezie je od těchto počátků až dosud Tomáš Vaněk. Během krátké doby se nové oddělení 
vypracovalo mezi přední česká kardiochirurgická pracoviště jak počty výkonů, tak i jejich spektrem a výsledky.

Dne 1. července 1996 zrrídila ředitelka FNKV Z. Roithová Kardiocentrum FNKV jakožto novou strukturu uvnitř nemocnice, horizontálně propojující tři pracoviště zabývající se léčbou kardiovaskulárních chorob: kardiologické oddělení na II. interní klinice (vedoucí Pavel Gregor), kardiologické oddělení na I. interní klinice (vedoucí Rudolf Špaček) a kardiochirurgické oddělení (primář Z byněk Straka). Vedoucím lékařem nového Kardiocentra jmenovala ředitelka Petra Widimského. Pracoviště rozvíjelo vedle nosného programu perkutánních koronárních intervencí (PCI) pro akutní infarkt myokardu a aortokoronárních bypassů pro akutní koronární syndromy i řadu dalších projektů: měření koronární rezervy, studium hypertrofických kardiomyopatií, rozvíjely se arytmologie (implantace kardiostimulátorů, elektrofyziologická vyšetření), miniinvazivní metody v kardiochirurgii atd. V roce 1998 byla k FNKV administrativně přičleněna i bývalá nemocnice ministerstva vnitra Na Míčánkách, která měla velmi slušné kardiologické oddělení vedené Pavlem Kohoutem a Václavem Bufkou. Toto oddělení se tak stalo čtvrtou součástí Kardiocentra FNKV. Tento historický vývoj (formování Kardiocentra FNKV ze čtyř různých oddělení) spolu s velkou přímou spádovou oblastí Praha 3, 10, 15 a 22 (240 000 obyvatel) způsobil, že se Kardiocentrum FNKV svou lůžkovou kapacitou 100 kardiologických lůžek (z toho 32 intenzivních) stalo největším kardiologickým pracovištěm v ČR.

Vývoj kardiologie ve FNKV byl završen zrrízením samostatné III. interní-kardiologické kliniky 1. srpna 2001. Jejím přednostou byl jmenován Petr Widimský, jeho zástupci Pavel Gregor, Rudolf Špaček a Martin Herold.

\section{Po roce 2001: současné Kardiocentrum FNKV}

$\mathrm{V}$ roce 2002 byla na klinice za účasti Václava Klause (obrázek 1) slavnostně otevřena moderní velká koronární jednotka: se čtyřmi resuscitačními a 16 intenzivními lůžky pravděpodobně největší v ČR.

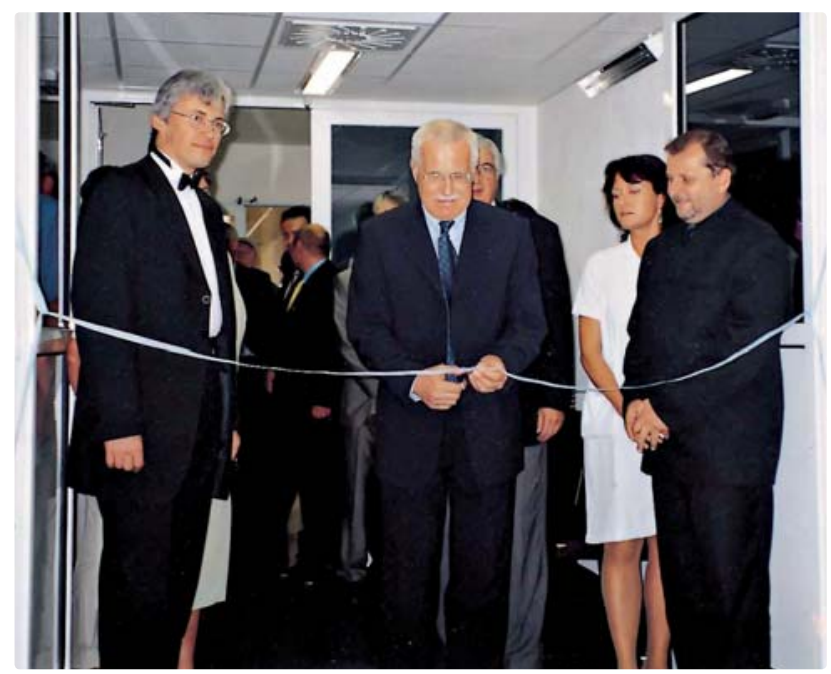

Obrázek 1 Václav Klaus slavnostně otevírá novou 20lůžkovou koronární jednotku

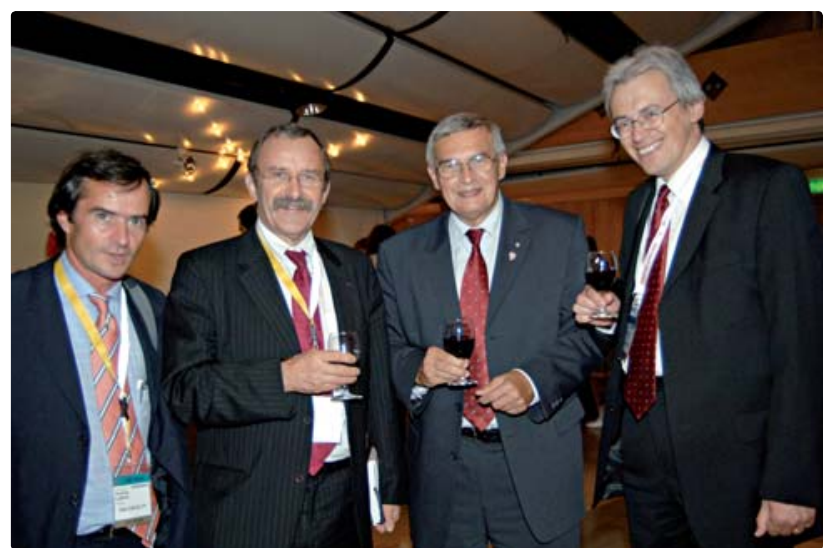

Obrázek 2 Slavnostní okamžik ideového zrodu Evropské asociace intervenční kardiologie (EAPCI). Zleva: Antoine Lafont (předseda Pracovní skupiny intervenční kardiologie ESC), Jean Marco (prezident EuroPCR), Michal Tendera (prezident ESC) a Petr Widimský (viceprezident ESC).

Lékaři kliniky se v letech 1990-2010 výrazně a opakovaně uplatnili i v různých funkcích ve výborech České kardiologické společnosti (ČKS), Evropské kardiologické společnosti (ESC), v Evropské asociaci intervenční kardiologie (EAPCI) (obrázek 2).

Pracoviště získalo mezinárodní věhlas a s počtem devíti prezentací výsledků vlastních (akademických, nefiremních) randomizovaných klinických studií v sekcích „Hot Line Trials“ (Evropa) či „Late Breaking Trials“ (USA) na velkých kardiologických kongresech patří mezi historicky nejúspěšnější akademická kardiologická pracoviště na světě. I aktuální publikační aktivita pracoviště je mimořádná - za rok 2009 publikovali lékaři Kardiocentra FNKV celkem 21 článků v zahraničních časopisech s impact faktorem.

V roce 2008 byl ze II. interní kliniky pod kardiologickou kliniku převeden celý obor angiologie (vedoucí Miroslav Bulvas). V roce 2009 získalo Kardiocentrum FNKV od MZ ČR statut komplexního kardiovaskulárního centra. V té

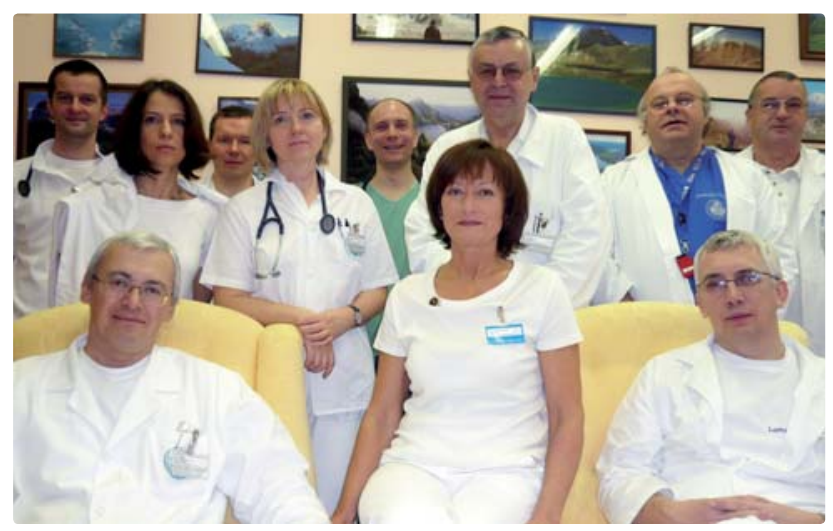

Obrázek 3 Současný tým vedoucích lékařů Kardiologické kliniky a vrchní sestra.

Vpředu sedící (zleva): Petr Widimský, Markéta Chocholová, Martin Herold. Vzadu stojící (zleva): Filip Roháč, Hana Línková, Pavel Osmančík, Zuzana Motovská, Viktor Kočka, Pavel Gregor, Miroslav Bulvas, Václav Bufka. (Na fotografii chybí z vedoucích lékařů Dalibor Heřman, Jaroslav Ulman a František Bednár.) 


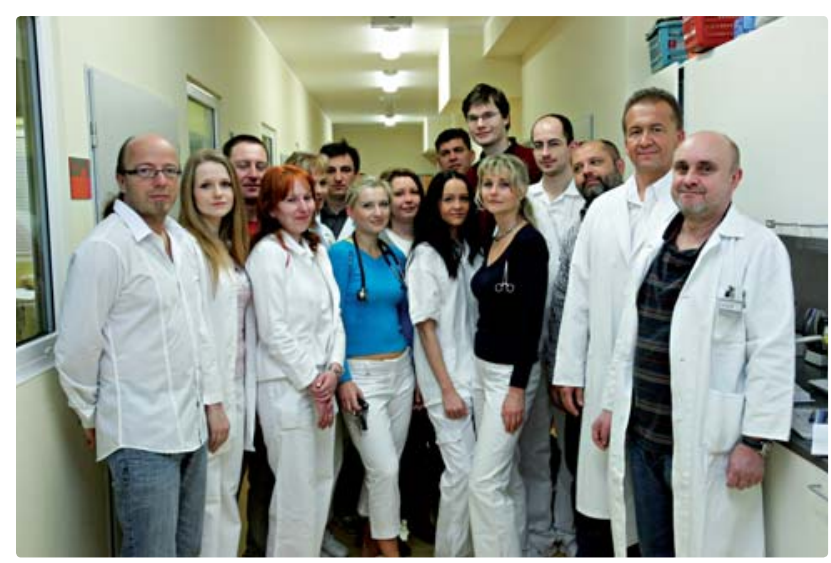

Obrázek 4 Současný tým Kardiochirurgické kliniky FNKV

souvislosti se součástí kardiocentra staly i obory cévní chirurgie (provozovaný v rámci Chirurgické kliniky FNKV, vedoucí Ivan Vaněk) a intervenční radiologie (provozovaný $\mathrm{v}$ rámci Radiodiagnostické kliniky FNKV, přednosta Václav Janík). Cévní chirurgie se v současné době ve FNKV začíná dynamicky rozvíjet, a doplňuje tak spektrum oborů v rámci kardiocentra.

Kardiocentrum FNKV a 3. LF UK je v současné době složeno ze dvou klinik (kardiologické a kardiochirurgické viz výše) a z osmi divizí:

> divize akutní kardiologie (vedoucí Zuzana Motovská), > divize intervenční kardiologie (vedoucí Viktor Kočka),

divize arytmologie (vedoucí Pavel Osmančík),

divize angiologie (vedoucí Miroslav Bulvas),

divize neinvazivní kardiologie (vedoucí Hana Línková),

divize kardiochirurgie (Zbyněk Straka),

divize kardioanestezie (Tomáš Vaněk),

divize cévní chirurgie (Ivan Vaněk).

Díky velmi dobře sehranému a mladému týmu lékařơ i sester (obrázky $3 a 4$ ) a podpoře moderně uvažujícího managementu FNKV (ředitel Marek Zeman) i podpoře vedení 3. lékařské fakulty Univerzity Karlovy (děkan Michal Anděl) jsou i další perspektivy rozvoje těchto oborů na Královských Vinohradech velmi slibné. 